\title{
Erb and c-Kit Receptors Have Distinctive Patterns of Expression in Adult and Developing Taste Papillae and Taste Buds
}

\author{
Susan K. McLaughlin \\ Department of Neurobiology and Behavior, The State University of New York at Stony Brook, Stony Brook, \\ New York 11794
}

\begin{abstract}
Twenty four different protein tyrosine kinases (PTKs) were amplified from a taste-enriched cDNA library using PCR. The expression of four protein tyrosine kinase receptors (EGFR, ErbB2, ErbB3, and c-kit) was examined in adult and developing rat taste papillae. All four of these receptors were expressed in overlapping populations of differentiated taste cells within adult taste buds. Taste bud basal cells were ErbB2 ${ }^{+}$but did not express the other Erb receptors. During prenatal development, the Erb receptors were expressed extensively in the basal cells around developing papillae, and ErbB2 and c-kit immunoreactive neuronal fibers were seen in close association with taste papillae. In
\end{abstract}

early postnatal stages, ErbB2 ${ }^{+}$and ${\mathrm{c}-\mathrm{kit}^{+}}^{+}$neuronal fibers were often seen entering the taste papillae epithelium, where new taste buds form, and by postnatal day 2 (P2), individual ErbB2 ${ }^{+}$ and $\mathrm{c}-\mathrm{kit}^{+}$cells were seen in this region as well. Between P3 and P8, c-kit was highly expressed at the bottom of foliate papillae trenches. The extensive expression of the Erb and c-kit receptors in adult taste buds and in and around developing papillae suggests that these receptors may play a role in the prenatal and postnatal development of gustatory papillae and taste buds.

Key words: taste bud development; taste papillae development; protein tyrosine kinase; c-kit; EGFR; ErbB2; ErbB3
The sense of taste is mediated by specialized taste receptor cells that are organized into groups of 50-100 to form taste buds. Cells in adult taste buds are constantly regenerating (Beidler and Smallman, 1965), and thus new receptor cells continue to differentiate during the life-span of the animal. Extensive experiments have shown that the maintenance and differentiation of taste receptor cells in the adult animal is dependent on nerve innervation (Vintschgau and Honigschmied, 1876; Olmsted, 1921, 1922) and axonal transport (Sloan et al., 1983), where an interaction between specific nerves and the epithelium in predetermined regions of the tongue regenerates taste buds (Guth, 1958; Zalewski, 1969; Zalewski, 1970; Oakley, 1974). Gustatory nerves evidently produce a trophic factor that activates a program leading to the differentiation of stem cells located in the papilla epithelium.

In the axolotl, taste buds develop in the absence of innervation (Barlow et al., 1996; Barlow and Northcutt 1997); however, in mammals, normal taste bud formation is more dependent on innervation by gustatory neurons. Some fungiform taste buds can be detected in TrkB and BDNF knockout mice, in which the number of gustatory neurons is severely reduced (Fritzsch et al., 1997; Nosrat et al., 1997; Z hang et al., 1997; Oakley et al., 1998; Mistretta et al., 1999). However, the cytoarchitecture of the buds was disturbed; in addition, there was a large reduction in the number of vallate and foliate taste buds, and all three types of gustatory papillae were smaller or had an aberrant morphology, or both. These results point to differences between the development of vallate and foliate taste buds versus fungiform taste buds and agree with earlier experiments in which it was noted that fungiform taste buds are more resistant to denervation than taste buds of other papillae (Kinnman and Aldskogius, 1991; Barry and Savoy, 1993). They also suggest that in addition to epithelial-mesenchymal interactions (Farbman and Mbiene, 1991; Hall et al., 1999), normal morphological development of gustatory papillae may be dependent in part on neuronal factors.

Trophic factors from neurons and epithelial-mesenchymal inter-

Received Feb. 4, 2000; revised May 11, 2000; accepted May 17, 2000.

I thank Robert Margolskee for support during the initial phases of this work, and Joel Levine, Maurice Kernan, and Jane Dixon for critical readings of this manuscript. Correspondence should be addressed to Susan K. McLaughlin, Department of Neurobiology and Behavior, The State University of New York at Stony Brook, Stony Brook, NY 11794. E-mail: skmclaughlin@notes.cc.sunysb.edu.

Copyright (C) 2000 Society for Neuroscience $0270-6474 / 00 / 205679-\bullet \$ 15.00 / 0$ actions appear to be involved in the development of gustatory papillae and taste buds. In other tissues, similar types of processes are regulated by protein tyrosine kinases (PTKs) (for review, see Birchmeier et al., 1993; Burden and Yarden, 1997; Gassman and Lemke, 1997). Because of their diverse activities affecting a wide variety of cell types, PTKs could potentially be involved in taste bud and papilla development, taste receptor cell differentiation and turnover, and the formation of synapses between innervating neurons and taste receptor cells. There is little information about the expression of PTKs in and around taste papillae. In this study, we used degenerate PCRs to amplify PTKs from a taste-enriched cDNA library. Immunohistochemistry was used to analyze the expression of EGFR, ErbB2, ErbB3, and c-kit in taste papillae in the adult and developing animal.

\section{MATERIALS AND METHODS}

Male Sprague Dawley rats were purchased from Taconic Laboratories (Germantown, NY). Timed pregnant female rats were also purchased from Taconic. Embryonic day 0 (E0) designates the day the sperm plug was observed; postnatal day 0 (P0) designates the day of birth.

Amplification of protein tyrosine kinases using the PCR. Two degenerate primers corresponding to the catalytic kinase domain of PTKs were made on an Applied Biosystems DNA synthesizer. Three degenerate primers directed against the kinase domain of the Erb family of protein kinase receptors were purchased from Life Technologies (Gaithersburg, MD). Primer TIDVYM was an internal primer used as a nesting primer to increase the specificity of the PCR reaction. Primer information is summarized in Table 1.

The substrate for the PCR reactions was a previously constructed tasteenriched cDNA library (McLaughlin et al., 1992). The conditions for the PTK PCR were as follows: $94^{\circ} \mathrm{C}, 1 \mathrm{~min} ; 48-72^{\circ} \mathrm{C}$ with a rise time of $1^{\circ} \mathrm{C}$ per $4 \mathrm{sec}$ for $2 \mathrm{~min} ; 72^{\circ} \mathrm{C}, 3 \mathrm{~min}$, for three cycles followed by $94^{\circ} \mathrm{C}, 1 \mathrm{~min} ; 54^{\circ} \mathrm{C}$, $2 \mathrm{~min} ; 72^{\circ} \mathrm{C}, 3 \mathrm{~min}$; for a total of 30 additional cycles. The PCR reaction products were electrophoresed on a $1 \%$ agarose gel, a band of the expected size was excised, and the DNA was purified; a second PCR reaction was performed under the same conditions using $25 \%$ of the purified DNA from the first-round PCR reaction.

The conditions for the first-round Erb PCR (using QIAKGM and MVKCWM) were $94^{\circ} \mathrm{C}, 1 \mathrm{~min} ; 38^{\circ} \mathrm{C}, 1 \mathrm{~min} ; 72^{\circ} \mathrm{C}, 1 \mathrm{~min}$; for a total of 30 cycles. The PCR reaction was electrophoresed on a $1 \%$ agarose gel, a band of the expected size was excised, and the DNA was purified; a second PCR reaction was then performed (using the QIAKGM and TIDVYM primers) under the following conditions: $94^{\circ} \mathrm{C}, 1 \mathrm{~min} ; 40^{\circ} \mathrm{C}, 1 \mathrm{~min} ; 72^{\circ} \mathrm{C}, 1 \mathrm{~min}$; for three cycles followed by $94^{\circ} \mathrm{C}, 1 \mathrm{~min} ; 45^{\circ} \mathrm{C}, 1 \mathrm{~min} ; 72^{\circ} \mathrm{C}, 1 \mathrm{~min}$; for 30 additional cycles.

All PCR products were electrophoresed on $1 \%$ agarose gels, bands of the correct size were excised, and the DNA was purified and cloned into 
Table 1. Degenerate primers used for PCR amplification of protein tyrosine kinases

\begin{tabular}{llll} 
Primer & Specificity & Direction & Sequence \\
\hline HRDLAARN & PTKs & Sense & CCGGATCCA(Y)(M)GIGA(Y)(Y)GCICI(M)GIAA \\
D(V/I)WS $(\mathrm{Y} / \mathrm{F}) \mathrm{G}(\mathrm{V} / \mathrm{I})$ & PTKs & Anti-sense & CCGAATTCA(Y)ICC(R)(W)AIGACCAIAC(R)TC \\
QIAKGM & Erbs & Sense & GCGGATCCA(R)AT(W)GCIAA(R)GGIATG \\
TIDVYM & Erbs & Sense & GCGAATTCAT(R)TAIAC(R)TC(D)ATIGT \\
MVKCWM & Erbs & Anti-sense & CATCCA(R)CA(Y)TTIACCAT
\end{tabular}

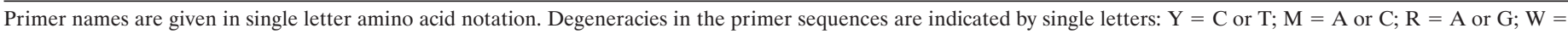

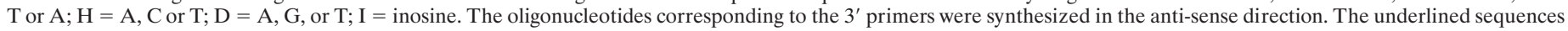
at the $5^{\prime}$ end of the oligonucleotides contain restriction endonuclease sites to facilitate cloning.

Table 2. Antibodies used for immunohistochemistry on circumvallate, foliate, and fungiform taste papillae

\begin{tabular}{llll} 
Antibody specificity & Species & Catalog number & Dilution \\
\hline EGFR & Rabbit & SC-03 & $1: 200$ \\
EGFR & Goat & SC-03G & $1: 200$ \\
ErbB2 & Rabbit & SC-07 & $1: 200$ \\
ErbB2 & Goat & SC-284G & $1: 200$ \\
ErbB3 & Rabbit & SC-285 & $1: 200$ \\
ErbB3 & Goat & SC-285G & $1: 200$ \\
c-Kit & Rabbit & SC-168 & $1: 200$ \\
Gustducin & Rabbit & SC-395 & $1: 2000$ \\
p75 & Rabbit & AB1554 & $1: 1000$ \\
$\beta$ IIII-tubulin & Mouse & TUJ1 & $1: 1000$
\end{tabular}

EGFR, ErbB2, ErbB3, c-kit, and gustducin antibodies were purchased from Santa Cruz Biotechnology; the anti- $\beta$ III-tubulin antibody was purchased from Babco (Richmond, CA), and the anti-p75 antibody was purchased from Chemicon (Temecula, CA). The species, catalog number, and the dilution at which each antibody was used is indicated.

pBluescript $\mathrm{KS}^{+}$(Stratagene, La Jolla, CA). The clones were sequenced using a Sequenase kit (Amersham Life Science, Cleveland, OH).

$R$ Nase protection assays. RNase protection assays were performed essentially as described in McLaughlin et al. (1992). In vitro transcription using T7 RNA polymerase (Promega, Madison, WI) was used to generate sense strand RNA from the taste-enriched and the non-taste lingual cDNA libraries. ${ }^{32} \mathrm{P}$-labeled antisense RNA probes coding for the various cloned PCR products were generated by in vitro transcription and annealed to 10 $\mu \mathrm{g}$ of sense strand taste or non-taste RNA. A ${ }^{32} \mathrm{P}$-labeled antisense actin probe was included in all reactions as an internal control. RNase protection assays were performed using the RPA II kit from Ambion (Austin, TX) according to their suggested protocol. The RNase protection assays (RPAs) were scanned on a Molecular Dynamics (Sunnyvale, CA) phosphorimager, and the amounts of protected RNA probes in the taste and non-taste cDNA libraries were compared using the Molecular Dynamics ImageQuant program.

Immunohistochemistry. Rats were anesthetized with carbon dioxide and then killed. Tongues were removed, rinsed in PBS, fixed in $4 \%$ paraformaldehyde for 2-3 hr at room temperature, and cryoprotected overnight with $20 \%$ sucrose in PBS. The tongues were embedded in OCT medium and cryostat-sectioned at $10-15 \mu \mathrm{m}$; sections were thaw-mounted on warm gelatin-subbed slides. Sections from at least three different animals were used in each of the adult expression experiments and for each of the antibodies at each developmental stage. Immunohistochemistry was performed in the following manner: sections were rinsed in PBS, then blocked with $1 \%$ donkey serum and $0.3 \%$ Triton X-100 in PBS for 30 min at room temperature; the blocking solution was removed and replaced with the primary antibody diluted in a solution of $0.3 \%$ Triton X-100 in PBS and incubated overnight at $4^{\circ} \mathrm{C}$. Sections were rinsed two times for $15 \mathrm{~min}$ in PBS, the secondary antibody was diluted in $0.3 \%$ Triton X-100 in PBS, and incubated with the sections for $30 \mathrm{~min}$ at room temperature. The sections were washed two times for $15 \mathrm{~min}$ in PBS, coverslipped, and viewed using fluorescence microscopy. Information about the primary antisera and the dilution at which each was used is listed in Table 2. Specific immunostaining was visualized with Cy3-conjugated $(1: 1000)$ or Cy2-conjugated $(1: 200)$ anti-rabbit or anti-goat IgG, and Cy2-conjugated (1:200) antimouse IgG; all were purchased from Jackson Immunoresearch Laboratories (West Grove, PA). To confirm the specificity of staining with the EGFR, ErbB2, ErbB3, gustducin, and c-kit antibodies, a blocking peptide for each antibody was purchased from Santa Cruz Biotechnology (Santa Cruz, CA). Preincubation of the antibody with the cognate peptide for 30 min on ice eliminated all staining; preincubation with a nonspecific peptide did not interfere with staining. To control for nonspecific staining caused by secondary antibody, each experiment included one section that was treated only with secondary antibody; staining was never seen in these cases.

\section{RESULTS}

\section{Several protein tyrosine kinases are expressed in elevated levels in a taste-enriched as compared with a non-taste lingual cDNA library}

Because of the difficulty in obtaining large quantities of mRNA from a pure population of taste cells, I used a taste-enriched cDNA library [constructed from poly $\left(\mathrm{A}^{+}\right)$mRNA isolated from circumvallate and foliate papillae (McLaughlin et al., 1992)] as the substrate for degenerate PCR. Degenerate PCR primers were designed against two highly conserved amino acid motifs located in the catalytic kinase domain of PTKs; these primers have been used successfully for the amplification of both receptor and nonreceptor protein tyrosine kinases (Lai and Lemke, 1991; Wilkie and Simon, 1991). The PCR products were cloned into pBluescript $\mathrm{KS}^{+}$and sequenced to determine their identity (Table 3 ). Two members of the Erb growth factor receptor family (ErbB2 and EGFR) were amplified from the taste-enriched cDNA library. Erb family members are known to heterodimerize, and the function of some of the family members (ErbB2 and ErbB3) requires heterodimerization. Therefore, in an attempt to isolate more Erbs from the taste library, I used degenerate primers specifically directed against Erb family PTKs in a second set of PCR reactions. When these Erbspecific primers were used, EGFR, ErbB2, and ErbB3 were amplified; ErbB4 was not detected.

As a strategy to identify genes expressed in taste buds, RPAs were used to compare PTK expression in taste-enriched versus non-taste lingual tissue. A PTK with elevated expression in tasteenriched tissue (as indicated by RPA) is more likely to be expressed in taste buds or in salivary duct cells than a PTK that is expressed in equivalent amounts in tissue from taste and non-taste areas of the tongue. I generated substrate taste RNA for the RPAs by in vitro transcription from the taste-enriched cDNA library described above; non-taste RNA was generated by in vitro transcription from a non-taste lingual cDNA library (McLaughlin et al., 1992). To compare the relative amounts of PTK RNA in the taste-enriched and non-taste cDNA libraries, actin was used as an internal standard, and the RPAs were quantified using a phosphorimager.

Figure 1 shows the results of the RNase protection experiments for those PTKs that were expressed in elevated levels in the taste-enriched cDNA library. Table 4 lists the PTKs that were examined and their fold expression in taste-enriched versus nontaste lingual cDNA libraries. Many PTKs are expressed in elevated levels in the taste-enriched cDNA library, suggesting that they are expressed in taste buds or in regions closely associated with circumvallate and foliate taste papillae. Interestingly, c-kit, EGFR, and ErbB3 were detected only in the taste cDNA library and were not found in the non-taste lingual library.

\section{Cells in adult rat taste buds express EGFR, ErbB2, ErbB3, and c-kit}

I chose to focus on the expression of the Erb growth factor receptors and the c-kit receptor for two reasons. First, these receptor tyrosine kinases (RTKs) regulate development and differentiation in a wide variety of tissues, including epithelia (for 


\begin{tabular}{lc}
\hline $\begin{array}{l}\text { Table 3. Receptor and nonreceptor PTKs amplified from the taste- } \\
\text { enriched cDNA library }\end{array}$ \\
Receptor PTK & Nonreceptor PTK \\
\hline EGFR family & Jak family \\
EGFR & Jak1 \\
ErbB2 & Tyk2 \\
ErbB3 & Jak3 \\
PDGFR family & Tec family \\
CSF1R & Tec \\
Flt & Bmx \\
Flk & cabl family \\
c-Kit & cabl \\
FGFR family & Unclassified \\
FGFR1 & Sik \\
FGFR2 (bek) & \\
Axl/Tyro3 family & \\
Axl (Mmufo) & \\
Sky & \\
Tie family & \\
Tie-1 & \\
Tie-2 (Tek) & \\
Insulin R family & \\
IGF1R & \\
Eph family & \\
EphA4 (Sek) & \\
Fak family & \\
Cak & \\
Unclassified & \\
Ryk & \\
\hline
\end{tabular}

The PTKs are divided into families based on sequence homology. Alternative names for the receptors are shown in parentheses.

review, see Besmer et al. 1993; Morrison-Graham and Takahashi, 1993; Burden and Yarden, 1997), and are thus good candidates for the regulation of taste papillae development and taste receptor cell differentiation. Second, c-kit, as well as two Erb family members (EGFR and ErbB3), could be detected by RPA only in the tasteenriched cDNA library; these genes were therefore the best candidates for specific expression in taste buds.

Taste buds are localized on the tongue within three different types of taste papillae: circumvallate and foliate papillae are located at the posterior part of the tongue, and contain hundreds of taste buds, whereas fungiform papillae are scattered over the anterior two-thirds of the tongue's surface and usually contain a single taste bud. Immunohistochemistry using commercial polyclonal rabbit antisera directed against EGFR, ErbB2, ErbB3, and c-kit was performed on transverse adult rat tongue sections containing circumvallate, foliate, and fungiform taste buds. Representative pictures are shown in Figure 2. The staining pattern of each of these antibodies was essentially identical in taste buds found in all three types of papillae.

Each of the antibodies stained the membrane and cytoplasm of some taste cells. Many spindle-shaped taste cells were brightly immunopositive for EGFR (Fig. $2 A-C$ ), ErbB2 (Fig. $2 D-F$ ), and c-kit (Fig. $2 K-M)$. Bright ErbB3 ${ }^{+}$taste cells were seen only on rare occasions in taste buds of circumvallate papillae (Fig. $2 G$, arrows). Although individual ErbB ${ }^{+}$taste cells could be identified in foliate (Fig. $2 H$ ) and fungiform papillae (Fig. 2I), staining was generally punctate and diffuse. The anti-ErbB2 antibody stained many basal cells in taste buds (Fig. $2 E$ ) as well as basal cells in the epithelium making up the gustatory papillae (Fig. $2 D-F$ ) and basal cells in the lingual epithelium outside the taste papillae (data not shown). However, ErbB2 expression in the basal cells in taste buds and around taste papillae appeared to be higher than its expression in basal cells found in other regions of the tongue. A closer

\section{A. Non-receptor PTKs}

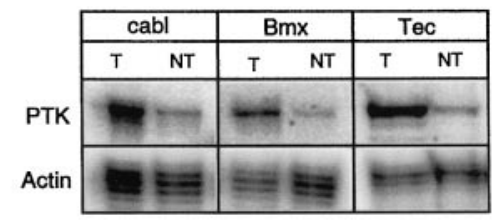

B. Receptor PTKs
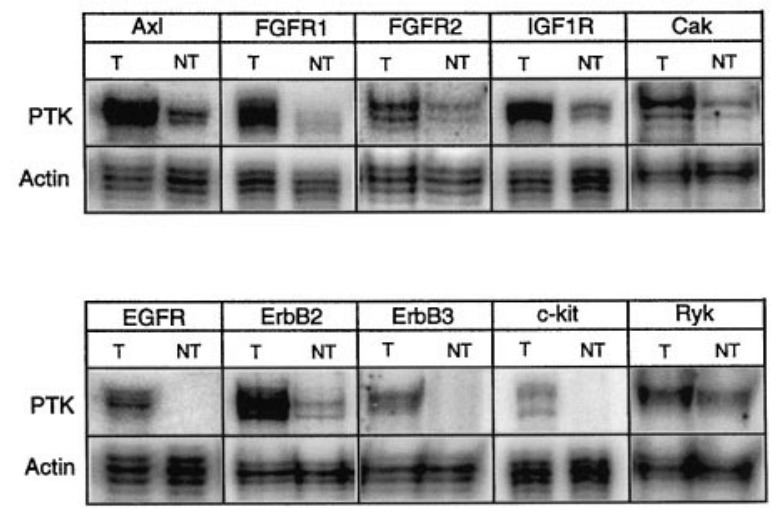

Figure 1. Expression of selected PTKs in the taste $(T)$ and non-taste $(N T)$ cDNA libraries. PTKs that were expressed in elevated levels in the taste cDNA library are shown; the receptor PTK Ryk is included as an example of a PTK that is expressed in equivalent amounts in the two libraries. Protected products for each PTK and the internal actin control are shown. Multiple protected products are caused by "breathing" at the ends of RNA, which is caused by the use of degenerate primers in the PCR reactions from which the probes are derived. Sizes of protected products: $c a b l=198$ base pairs (bp); Bmx = $196 \mathrm{bp} ;$ Tec $=198 \mathrm{bp} ; A x l=199 \mathrm{bp} ; F G F R 1=201 \mathrm{bp}$; $F G F R 2=200$ bp; IGFIR = 200 bp; Cak = 201 bp; EGFR = 377 bp; $E r b B 2=377$ bp; ErbB3 = 377bp; $c$-kit $=202$ bp; Ryk $=199$ bp.

examination of the ErbB2 ${ }^{+}$basal cells in taste buds (Fig. 2 E, arrow; $100 \times$ magnification) reveals that some of these cells appear to have a shape intermediate between that of a round basal cell with a nucleus at the bottom of the bud and that of a spindle-shaped mature taste cell, with a nucleus located near the middle of the bud. In addition to their expression inside taste buds, ErbB3 and EGFR were expressed in basal cells and stratified epithelial cells around fungiform papillae. c-Kit expression was primarily confined to

Table 4. PTK expression compared in taste versus non-taste cDNA libraries

\begin{tabular}{llll} 
Receptor PTK & $\begin{array}{l}\text { Fold elevation } \\
\text { Taste:non-taste }\end{array}$ & Non-receptor PTK & $\begin{array}{l}\text { Fold elevation } \\
\text { Taste:non-taste }\end{array}$ \\
\hline Axl & 5.3 & cabl & 6.8 \\
FGFR1 & 6.9 & Bmx & 4.6 \\
FGFR2 & 2.3 & Tec & 4.7 \\
IGF1R & 5.5 & & \\
Cak & 3.3 & & \\
EGFR & Taste only & & \\
ErbB2 & 7.4 & & \\
ErbB3 & Taste only & & \\
c-Kit & Taste only & & \\
Ryk & 1.3 & &
\end{tabular}

The expression of PTKs was examined in the taste-enriched and non-taste cDNA libraries using RNase protection and quantitated using a Molecular Dynamics scanner. The fold elevation of each of these isolates in taste versus non-taste is shown. EGFR, ErbB3, and c-kit were detected only in the taste cDNA library. PTKs not detected by RPA: CSF1-R, Sik, Sky; PTKs expressed in equivalent amounts or in greater amounts in the non-taste library: Ryk, Flt, Tie; PTKs not examined: Tyk2, Jak1, Jak3, Flk, EphA4. 
Circumvallate

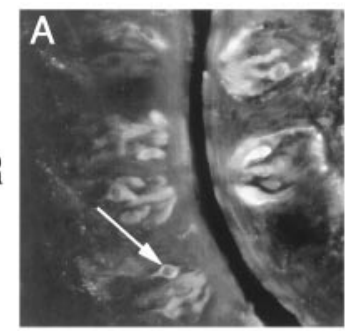

EGFR

Figure 2. Expression of Erb PTKs and c-kit in transverse sections of adult circumvallate, foliate, and fungiform taste papillae. Arrows indicate the location of some positively stained taste cells. Elongated EGFR ${ }^{+}$cells are seen in circumvallate $(A)$, foliate $(B)$, and fungiform $(C)$ taste buds. Spindle-shaped ErbB2 ${ }^{+}$cells are found inside buds of all three taste papillae $(D, E)$. ErbB2 ${ }^{+}$basal cells $(b c)$ can be identified around the three taste papillae; a higher magnification of a single foliate taste bud $(E, 100 \times)$ shows ErbB2 ${ }^{+}$basal cells near the base $(b)$ of a taste bud. Two intensely stained ErbB3 ${ }^{+}$ cells can be seen (arrows) in taste buds of a circumvallate papillae $(G)$. These very bright ErbB3 $^{+}$cells were only observed in circumvallate taste buds; ErbB $3^{+}$cells inside foliate $(H)$ and fungiform $(I)$ taste buds exhibited less intense and more diffuse staining. Very bright c-kit ${ }^{+}$cells were observed in taste buds of all three taste papillae $(J-L)$. Scale bar: For all panels with the exception of $E, 100 \times$ and fungiform panels $(C, F, I, L)$, scale bar is 35 $\mu \mathrm{m}$; scale bar for $E, 100 \times$ panel is $20 \mu \mathrm{m}$; scale bar for fungiform panels $(C, F, I, L)$ is $25 \mu \mathrm{m}$.
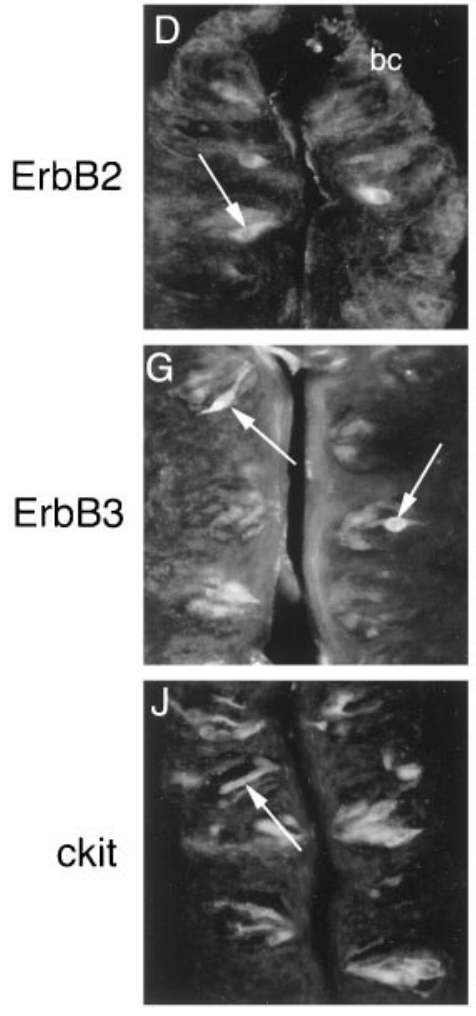

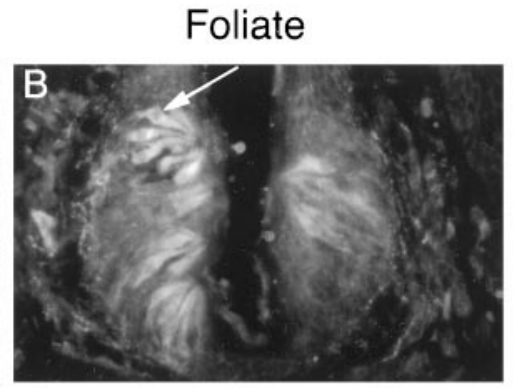

\section{Fungiform}
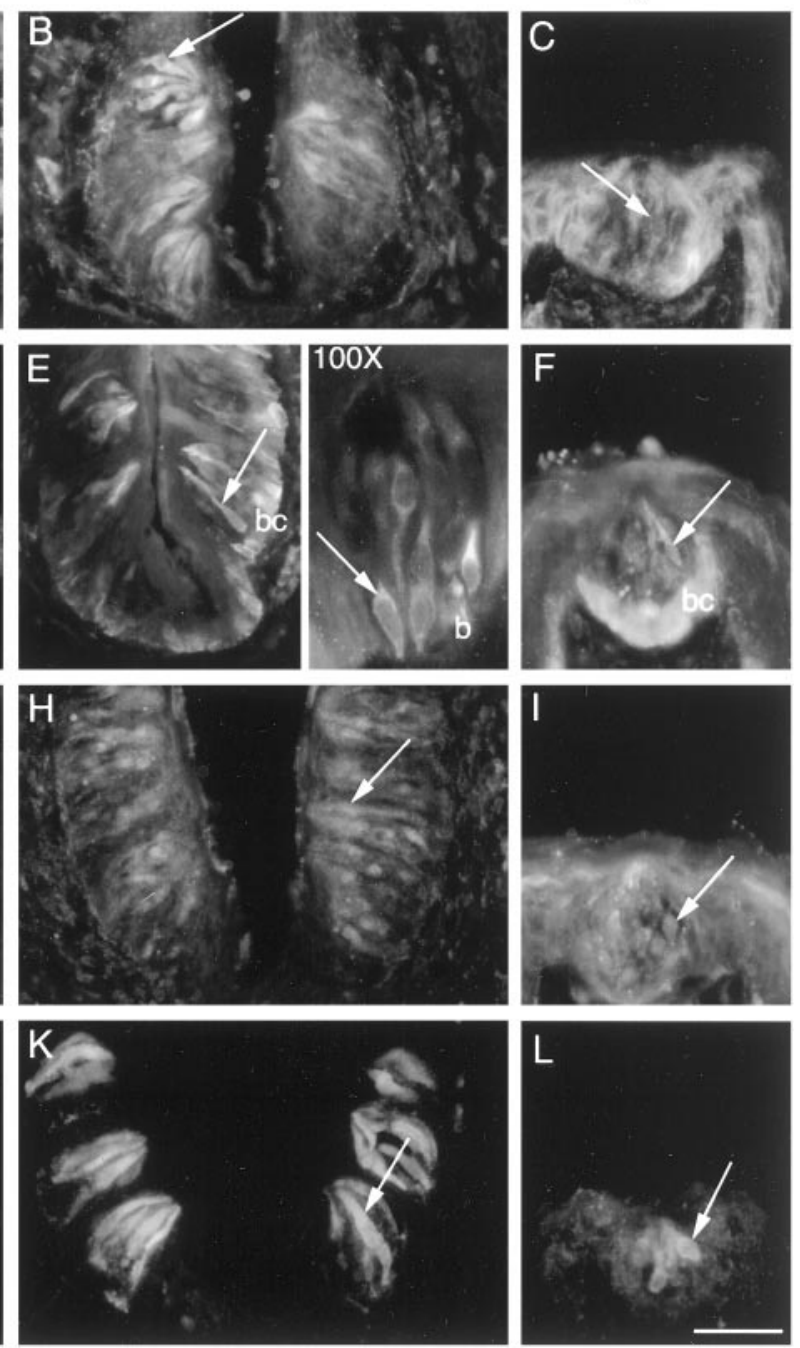

spindle-shaped cells within taste buds and was not generally seen in the surrounding lingual epithelium or mesenchyme.

\section{The Erb PTKs and c-kit are expressed in overlapping populations of taste cells}

Double immunohistochemistry was performed to determine whether the taste cells expressing the Erb and c-kit receptors represent overlapping populations or whether there are specific types of cells that express each particular receptor. All six possible combinations of the Erb and c-kit antibodies were tested. Cells of different morphological types can be detected inside taste buds (for review, see Roper, 1989). The functions of these different cell types have not yet been definitively determined, and not all cells within taste buds are necessarily taste receptors. Therefore, as a marker for taste receptor cells, I used an anti-gustducin antibody with the anti-Erb antibodies in double immunohistochemistry experiments. Gustducin is a G-protein $\alpha$-subunit that plays a role in sweet and bitter taste transduction (Wong et al., 1996) and is a marker for a subset of type II taste receptor cells (Boughter et al., 1997). Double staining was not performed for gustducin and c-kit because both primary antibodies were made in the same species (rabbit).

I detected each of the six combinations of two PTKs in individual taste cells (Fig. 3). In an occasional taste cell, only one PTK was predominantly expressed. Because of the rarity of the very bright $\mathrm{ErbB}^{+}$cells, I could not definitively determine whether these cells commonly express another Erb receptor; however, the more faintly labeled ErbB3 ${ }^{+}$cells often expressed ErbB2 or EGFR. Most cells that expressed one of the Erb receptors also expressed gustducin, indicating that some type II taste receptor cells express the Erb receptors; however, Erb ${ }^{+}$gustducin ${ }^{-}$and Erb ${ }^{-}$gustducin ${ }^{+}$cells were also seen in taste buds. It is notable that the ErbB2 ${ }^{+}$basal cells in taste buds and around the taste papillae did not express the other Erb family members or gustducin.

\section{The Erb and c-kit receptors have different patterns of expression during prenatal and postnatal development}

To ascertain whether the Erb or c-kit receptors might play a role in taste papilla or taste bud development, I examined the expression of EGFR, ErbB2, ErbB3, and c-kit in E16-P10 circumvallate and foliate papillae. In the rat, circumvallate and foliate papillae begin to form around E14-E15 (Mistretta, 1972; Mbiene et al., 1997), when the epithelium covering the tongue invaginates into the mesenchyme. Nerves can be seen in the core of the circumvallate papillae at E16 (Mbiene and Mistretta, 1997), and immature taste buds can be morphologically identified as early as E20 (Mistretta, 1972; Bradley and Mistretta, 1988). As development proceeds, the epithelium of the papillary trenches thickens, and more taste buds begin to appear in this region. There are relatively few mature taste buds (i.e., functional buds with an open taste pore) before P5. Taste buds continue to be added to the papillae over a period of $\sim 3$ months, with the greatest amount of addition as well as the fastest maturation rate occurring in early neonates (Hosley and Oakley, 1987; Oakley et al., 1991).

Transverse sections from papillae at the following developmental stages were examined in these experiments: E16, E18, E20, P0 (day of birth), P1, P2, P3, P5, P6, P7, P8, and P10. For convenience, 

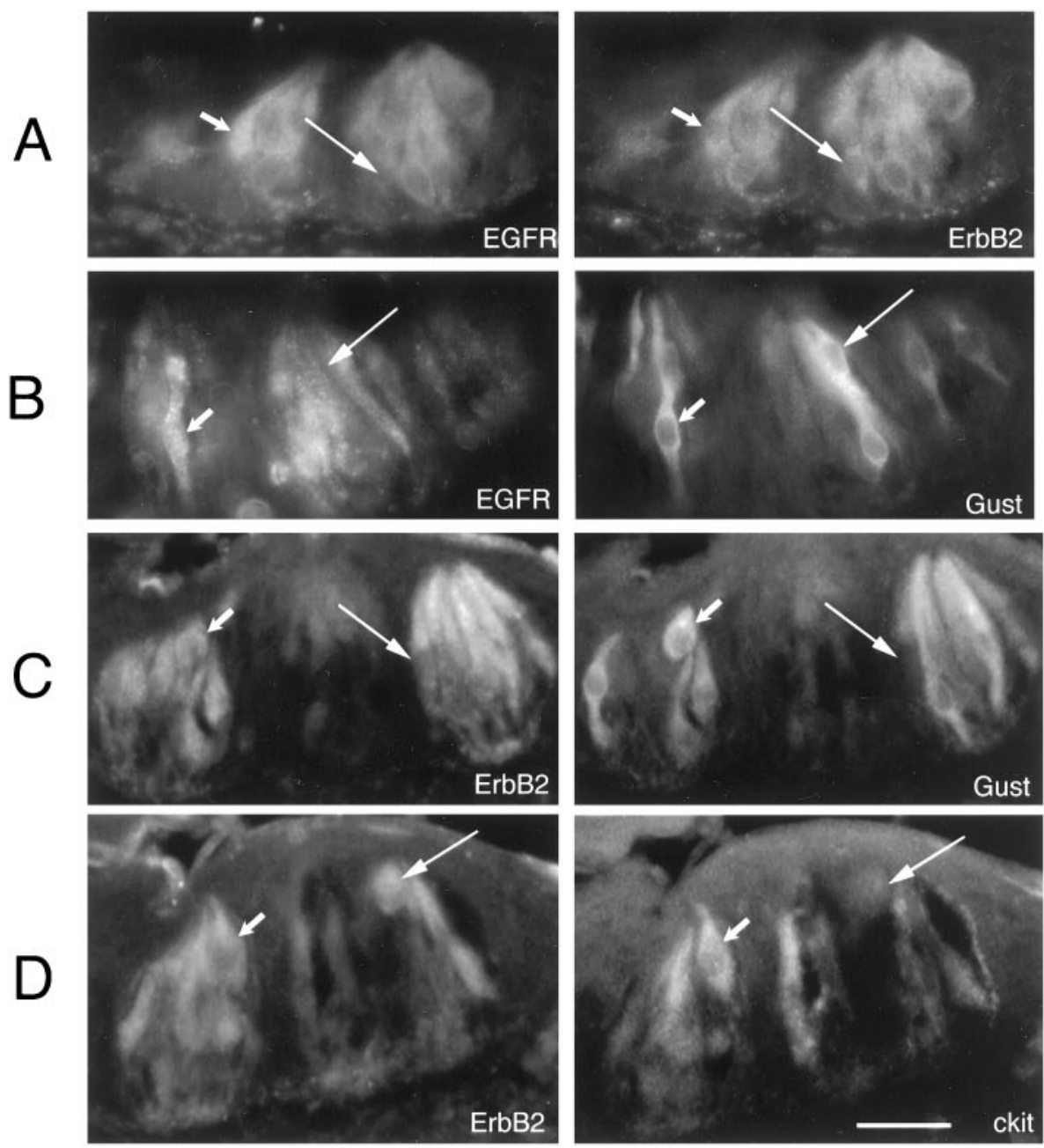

Figure 3. Paired photographs are shown from double immunohistochemistry experiments used to examine the coexpression of EGFR, ErbB2, ErbB3, c-kit, and gustducin in single taste cells from circumvallate papillae. $A, \mathrm{EGFR}+$ ErbB2; $B, \mathrm{EGFR}+$ gustducin; $C$, ErbB2 + gustducin; $D$, ErbB2 + c-kit. The antibody showing visible staining is indicated in the bottom right corner of each panel. Gust, gustducin. The figures are oriented such that the top of the taste buds is at the top of the panel. Many cells exhibit double immunolabeling (short arrows), indicating the extensive overlap in the expression of these PTK receptors; however, some single-labeled cells (long arrows) can be seen. These sections were chosen specifically because they contained single-labeled cells; single-labeled cells are actually quite rare. Scale bar (shown in $D$, right panel ): $20 \mu \mathrm{m}$ for all panels. development is broken down into four stages: (1) E16-E20 (prenatal), (2) P0-P3 (early neonate), (3) P5-P8 (neonate), and (4) P10. Between E16 and E20, the foliate and circumvallate papillae consist of invaginations of the basal cell layer of the epithelium into the lingual mesenchyme. By $\mathrm{P} 0$, the basal cell layer is beginning to separate from a more disorganized layer of cells that is forming closer to the cleft of the papilla. It is in this disorganized layer of the epithelium that taste buds appear. As development proceeds, the papilla deepens, and increasing numbers of taste buds are added to the papilla epithelium. By P10, the general morphology of the papilla is essentially that seen in an adult animal. Representative pictures of the expression pattern of each of the receptors in a foliate papilla at each of the developmental stages are shown in Figure 4 (EGFR), Figure 5 (ErbB2), Figure 6 (ErbB3), and Figure 7 (c-kit). Figure 8 presents the collected data in a tabular form. There was essentially no difference in RTK expression in foliate and circumvallate papillae, although some distinctive patterns of expression were seen more easily in one type of papilla rather than the other.

\section{EGFR}

Between E16 and E20, the anti-EGFR antibody intensely stains the membrane of epithelial basal cells located in the invaginations of developing taste papillae, as well as the basal cells and stratified epithelium on the rest of the tongue's surface (Fig. 4). The staining intensity drops after birth, and the papilla epithelium continues to stain positively for EGFR through P10, although at much reduced levels. The brightest epithelial staining in the gustatory papillae is on the top and bottom of foliate trenches and the tips of circumvallate trenches. Between $\mathrm{P} 0$ and $\mathrm{P} 8$, most of the cells in the disorganized epithelium of the gustatory papillae are $\mathrm{EGFR}^{+}$, and
$\mathrm{EGFR}^{+}$cells can be seen inside developing taste buds as they are added to the papillae epithelium. By P10, the staining pattern is similar to that of the adult, and numerous spindle-shaped cells inside taste buds are $\mathrm{EGFR}^{+}$.

\section{$\operatorname{ErbB2}$}

Before birth, the anti-ErbB2 antibody stains the basal cell layer of the lingual epithelium, both inside the developing gustatory papillae and on the rest of the tongue (Fig. 5). Unlike EGFR staining, ErbB2 staining is primarily restricted to basal cells and generally not seen in the stratified layer of the epithelium. Between P0 and P8, the most intensely stained basal cells are at the top and bottom of the foliate papillae trenches and at the tips of the circumvallate trench.

At E16, fibers around the developing taste papillae and within the papillary cores exhibit bright staining with anti-ErbB2. Although there is a dense accumulation of these fibers around the gustatory papillae, ErbB2 ${ }^{+}$fibers can also be detected in non-taste regions of the tongue. By $\mathrm{P} 3, \mathrm{ErbB} 2^{+}$fibers can be seen within the papillae epithelium where taste buds are being formed and can be seen occasionally inside developing taste buds. When the embryonic innervation of the rat circumvallate papillae was examined (Mbiene and Mistretta, 1997), intense neuronal staining was seen in the core of the circumvallate papillae beginning at E15, presumably from the glossopharyngeal nerve. To determine whether the ErbB2 ${ }^{+}$fibers are neuronal, a mouse monoclonal anti- $\beta$ III-tubulin antibody (TUJ1) was used as a marker for neurons (Lee et al., 1990). Double immunohistochemistry (data not shown) indicated that ErbB2 ${ }^{+}$fibers overlapped with $\mathrm{TUJ} 1{ }^{+}$fibers, suggesting that the stained fibers in the papillary cores are neuronal. ErbB2 ${ }^{+}$fibers in the papillary core also overlapped with p $75^{+}$immunostaining, so 
E20
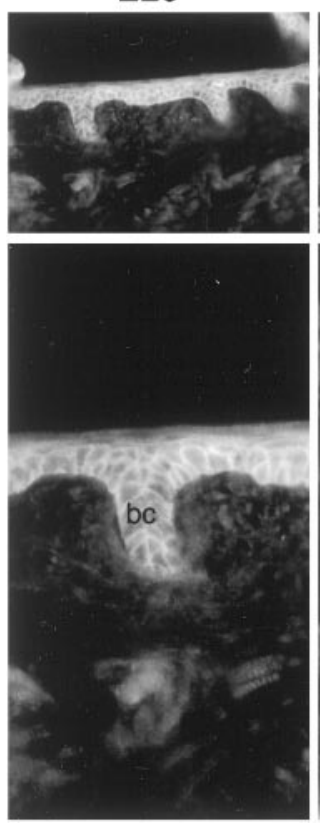

E20
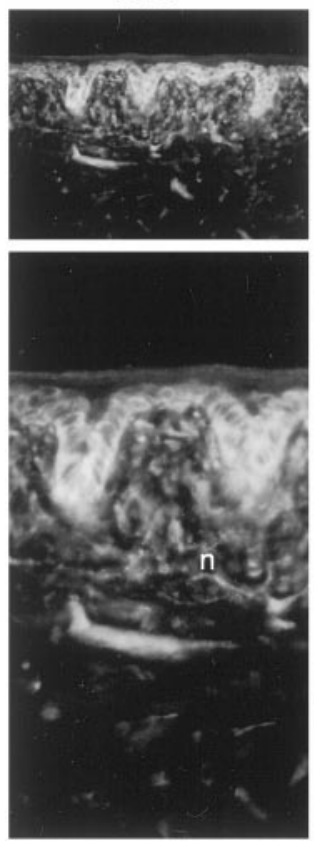

P2
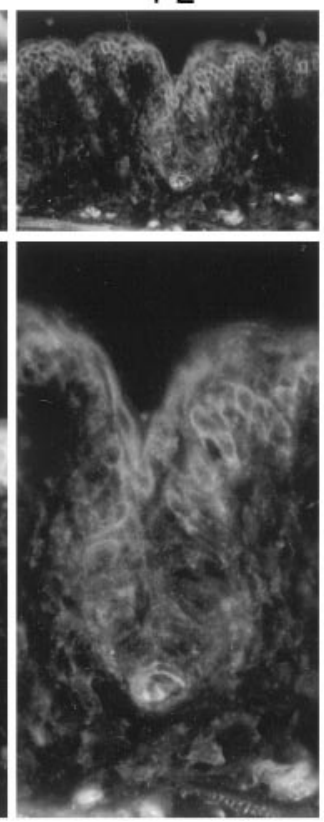

P3
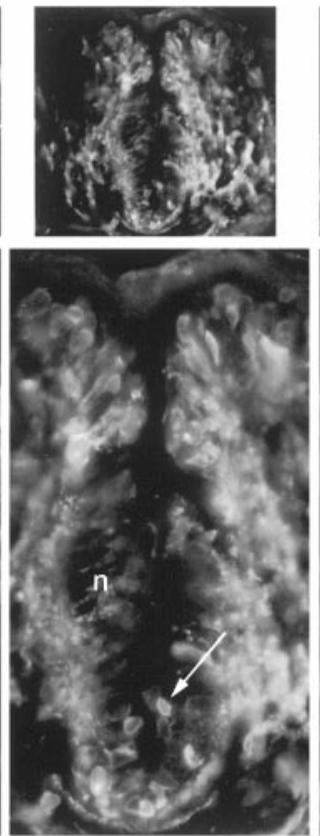

P5
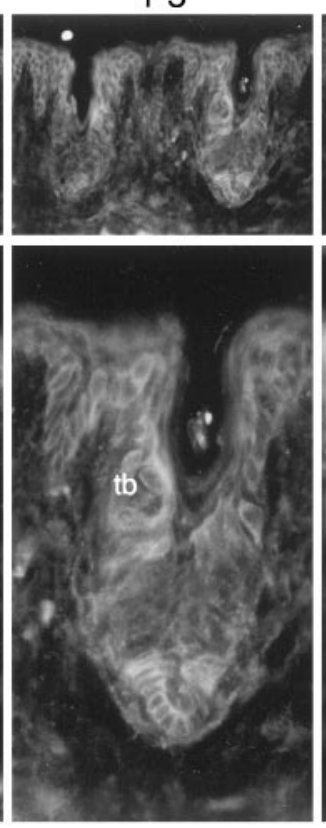

P6
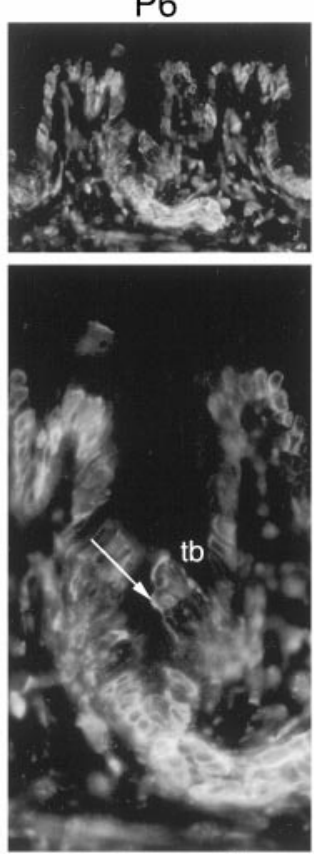

P10
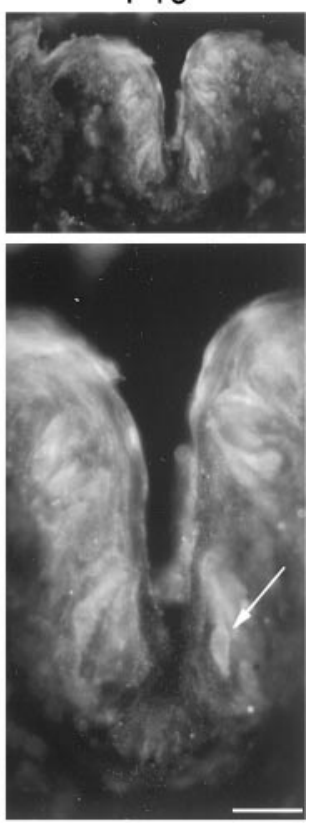

Figure 5. Expression of ErbB2 in developing foliate papillae. This Figure is organized in the same way as Figure 4. Prenatal epithelial basal cells exhibit intense ErbB2 staining and continue to do so in the adult, although the staining intensity decreases. However, unlike EGFR, ErbB2 does not appear to stain the stratified epithelium. ErbB2 ${ }^{+}$neuronal fibers $(n)$ are found in close association with the papillae trenches during prenatal and early postnatal development. These fibers are occasionally seen entering the papillae epithelium $(P 3, n ; P 6$, arrow) where taste buds $(t b)$ are beginning to appear. Individual round ErbB2 ${ }^{+}$cells, which may be recently differentiated taste receptor cells, can be identified in the papillae epithelium early during postnatal development (P3, arrow). At $\mathrm{P} 10$, ErbB2 is expressed in cells within taste buds. Scale bar in P10, bottom panel, is 200 $\mu \mathrm{m}$ for the smats.

some of this ErbB2 ${ }^{+}$immunoreactivity could be attributable to Schwann cells. However, the fact that ErbB2 ${ }^{+}$fibers were also seen inside taste buds suggests that at least in some cases they are neuronal. Between P5 and P8, the intensity of the fibrous staining around the gustatory papillae is reduced. By $\mathrm{P} 2$, isolated round $\mathrm{ErbB}_{2}{ }^{+}$cells are detected in the papillae epithelium, and as taste buds develop, more spindle-shaped ErbB2 ${ }^{+}$cells appear. With the exception of the basal cell layer, the epithelium in the papilla between developing taste buds is not stained by the ErbB2 antibody. By P10, ErbB2 staining resembles that seen in the adult animal.

\section{$\operatorname{ErbB3}$}

Between E16 and E20, there is moderate staining of the papillary core and epithelium with the anti-ErbB3 antibody (Fig. 6). The staining of the non-taste papillary epithelium by the ErbB3 antibody decreases significantly after P 3 and has disappeared by

P8. By P2, round cells exhibiting a moderate, diffuse ErbB3 ${ }^{+}$ staining can occasionally be detected in the taste bud-forming region of the papillae; ErbB3 ${ }^{+}$staining in these cells is more diff use and less intense than that seen with other Erb antibodies. Increasing numbers of these cells are seen as taste buds are added to the papillae. ErbB3 staining of taste cells at P10 is usually less intense than that for the other PTKs; however, it is more intense than the ErbB3 staining commonly seen in adult papillae.

\section{c-Kit}

In a pattern similar to that seen with ErbB2, fibers around the prenatal and postnatal developing papillae stain positive for c-kit. By P3, c-kit ${ }^{+}$processes can be seen within the papillary epithelium (Fig. 7). Double immunohistochemistry with the TUJ1 antibody and the c-kit antibody suggested that the c-kit ${ }^{+}$ fibers are neuronal, and at least some of the c-kit ${ }^{+}$fibers in the 

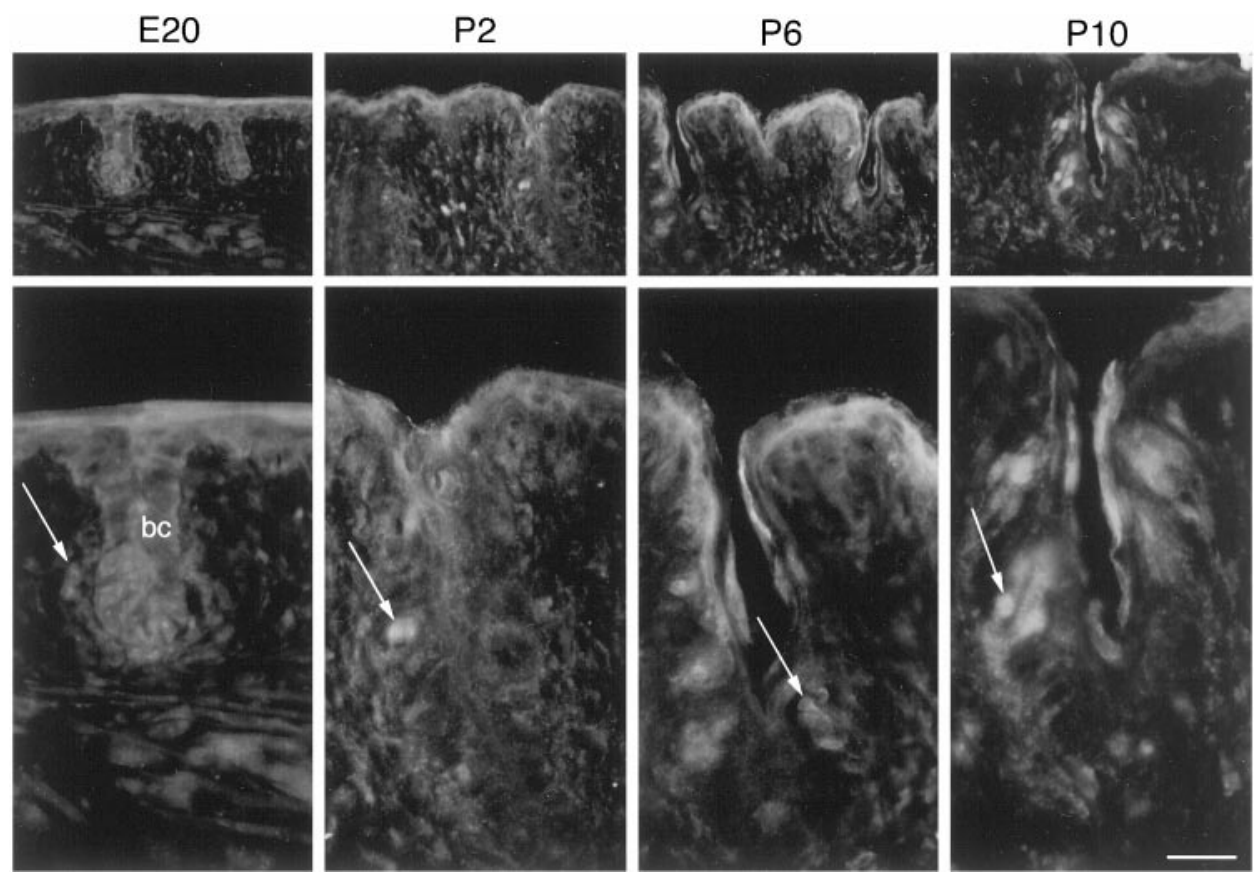

E16
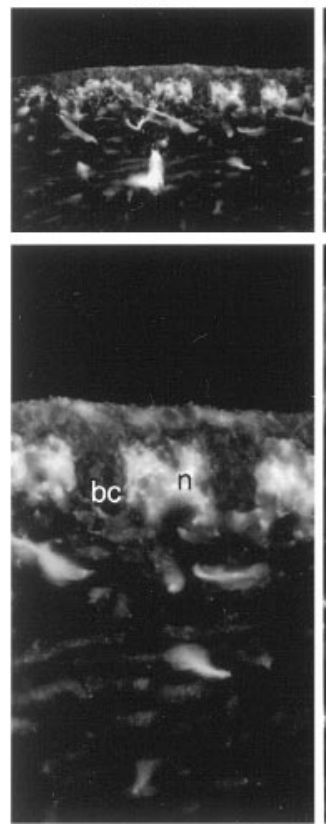

P3
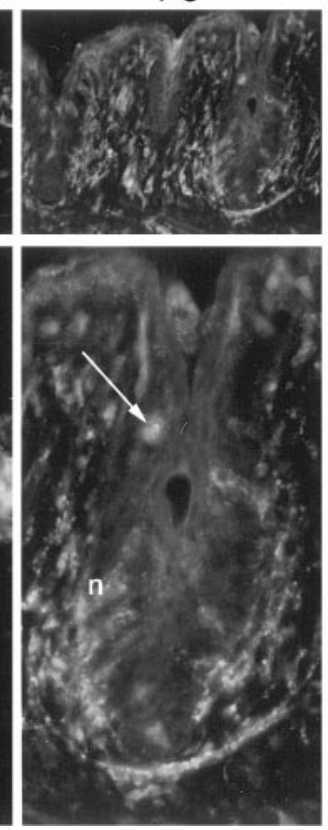

P6
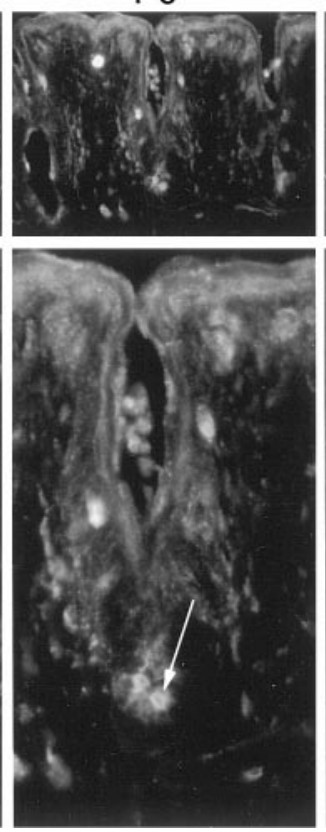

P10
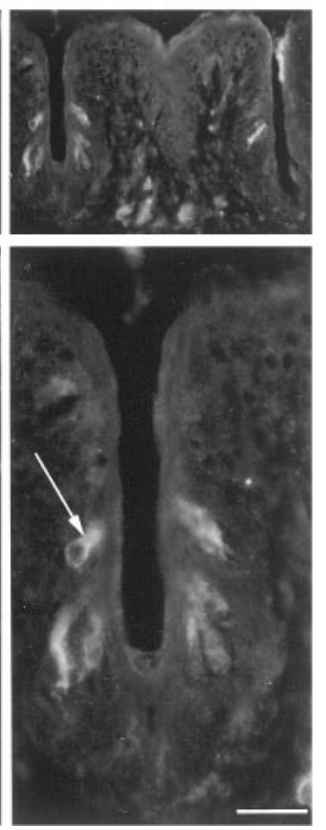

Figure 6. Expression of ErbB3 in developing foliate papillae. This Figure is organized in the same way as Figure 4. Faint, fibrous ErbB3 staining is seen around the papillae (E20, arrow) during prenatal development; the staining intensity diminishes after birth. Individual ErbB3 ${ }^{+}$cells are occasionally seen early in postnatal development (P2, arrow); the number of these cells increases as development proceeds (P6, arrow; P10, arrow). Scale bar in P10, bottom panel, is $200 \mu \mathrm{m}$ for the smaller panels and $75 \mu \mathrm{m}$ for the larger panels.
Figure 7. Expression of c-kit in developing foliate papillae. This Figure is organized in the same way as Figure 4. Neuronal staining ( $n$ ) by c-kit can be distinguished around taste papillae during prenatal development (E16) and continues through the early stages of postnatal development $(P 3, P 6)$. By P10 this neuronal staining has almost disappeared. By $\mathrm{P} 2$, individual c-kit ${ }^{+}$cells can be seen in the papilla epithelium (P3, arrow); the number of these cells increases as the developing taste buds mature and more buds are added to the papillae. An intense, punctate c-kit ${ }^{+}$staining appears at the bottom of foliate papillae trenches $(P 6$, arrow $)$, which is at its height around P6. Scale bar in P10, bottom panel, is $200 \mu \mathrm{m}$ for the smaller panels and $75 \mu \mathrm{m}$ for the larger panels. papilla core appeared to be ErbB2 ${ }^{+}$as well (data not shown). As with ErbB2, c-kit ${ }^{+}$fibers can be seen on the tongue outside of the gustatory papillae. By P5, the staining intensity of the c-kit ${ }^{+}$ fibers is reduced, and it is almost entirely gone by P10. At P1, rare ${\mathrm{c}-\mathrm{kit}^{+}}^{+}$cells were observed in the taste papillae epithelium, and increasing numbers of $\mathrm{c}-\mathrm{kit}^{+}$cells appeared in this region by $\mathrm{P} 2$. At P3, a slight, punctate c-kit ${ }^{+}$staining was seen at the bottom of some foliate trenches and at the ends of the circumvallate papilla trench (the part of the papilla nearest the anterior end of the tongue). By P5, a similar type of staining could be detected around the curve of the vallate papillae (nearer the posterior end of the tongue). The ${\mathrm{c}-\mathrm{kit}^{+}}^{+}$staining at the bottom of the foliate trenches is more easily distinguished than the staining in the vallate papillae. At the bottom of the foliate papillae trenches, $\mathrm{c}^{-\mathrm{kit}^{+}}{ }^{+}$staining is at its most intense at P6 and has diminished by P8. At P10, numerous spindle-shaped c-kit ${ }^{+}$ cells could be seen in the papilla epithelium.

\section{DISCUSSION}

A combination of PCR and RNase protection analysis was used to isolate PTKs from gustatory tissue and screen them for their potential expression in taste buds. When the expression of four RTKs (EGFR, ErbB2, ErbB3, and c-kit) was examined in adult taste papillae, all four were found to be expressed in taste buds. Only ErbB2 was detected in significant levels outside taste buds, and it was the only RTK of the four that was detected by RPA in the non-taste lingual library. These results suggest that other PTKs expressed in elevated levels in the taste-enriched library (Axl FGFR1, FGFR2, IGF1-R, cabl, Cak) may also be expressed in taste buds.

\section{Erb receptors in adult taste buds}

EGFR, ErbB2, and ErbB3 could all be detected in differentiated taste cells in adult rat taste buds, although intensely stained $\mathrm{ErbB}^{+}$cells were relatively rare. Most taste cells expressed more 


\begin{tabular}{|c|c|c|c|c|c|c|c|c|c|}
\hline & & \multicolumn{2}{|c|}{ E16 - E20 } & \multicolumn{2}{|c|}{ P0 - P3 } & \multicolumn{2}{|c|}{ P5 - P8 } & \multicolumn{2}{|c|}{$\mathbf{P 1 0}$} \\
\hline Cell Type & Antibody & \# cells & $\begin{array}{l}\text { staining } \\
\text { intensity }\end{array}$ & \# cells & $\begin{array}{c}\text { staining } \\
\text { intensity }\end{array}$ & \# cells & $\begin{array}{c}\text { staining } \\
\text { intensity }\end{array}$ & \# cells & $\begin{array}{c}\text { staining } \\
\text { intensity }\end{array}$ \\
\hline \multirow{4}{*}{ Basal cells } & EGFR & ++++ & ++++ & +++ & ++ & & ++ & ++ & ++ \\
\hline & ErbB2 & ++++ & ++++ & +++ & ++++ & +++ & +++ & ++ & +++ \\
\hline & ErbB3 & ++++ & + & - & - & - & - & - & - \\
\hline & c-kit & ++++ & + & - & - & - & - & - & - \\
\hline \multirow{4}{*}{ Papilla epithelium } & EGFR & & & ++++ & ++ & +++ & ++ & +++ & ++ \\
\hline & ErbB2 & & & - & - & - & - & - & - \\
\hline & ErbB3 & & & ++++ & + & - & - & - & - \\
\hline & c-kit & & & - & - & - & - & - & - \\
\hline \multirow{4}{*}{ Papilla core } & EGFR & - & - & - & - & - & - & - & - \\
\hline & ErbB2 & +++ & ++++ & +++ & ++++ & ++ & ++ & + & ++ \\
\hline & ErbB3 & +++ & ++ & + & + & - & - & - & - \\
\hline & c-kit & +++ & ++++ & +++ & ++++ & ++ & + & - & - \\
\hline \multirow{4}{*}{$\begin{array}{c}\text { Developing Taste } \\
\text { Buds }\end{array}$} & EGFR & & & + & + & ++ & ++ & +++ & +++ \\
\hline & ErbB2 & & & + & +++ & ++ & +++ & +++ & +++ \\
\hline & ErbB3 & & & + & ++ & ++ & ++ & +++ & ++ \\
\hline & c-kit & & & + & +++ & ++ & ++++ & +++ & ++++ \\
\hline
\end{tabular}

Figure 8. Expression data for the Erb and c-kit receptors during development is quantitated for four main regions of the foliate papilla: basal cells ( $b c)$, the papilla epithelium $(p e)$, the papilla core $(p c)$, and developing taste buds $(t b)$. The location of these regions is indicated in the large diagram representing a developing foliate papilla; additional diagrams are located above each column, representing foliate papillae during the developmental stages examined. The number of cells expressing each receptor and the staining intensity are indicated. $++++=$ all cells or very intense staining; $+++=$ many cells or bright staining; $++=$ some cells or moderate staining; $+=$ few cells or faint staining; $-=$ no cells or no staining. Because no papillae epithelium or developing taste buds were seen in the E16-E20 stages, this column was left blank.

than one Erb receptor, and both EGFR and ErbB2 coexpressed with gustducin, indicating that these Erb receptors can be found in some type II taste receptor cells, which are believed to serve a sensory function. The distinctive RTK staining patterns exhibited by taste cells could define different cell lineages, each of which expresses a different combination of RTKs. Alternatively, these receptors could be expressed at different but overlapping stages during taste cell maturation. The expression of EGFR, ErbB2, and ErbB3 in adult rat taste buds, and their coexpression in single taste cells, indicates that many of these cells are capable of responding to Erb ligands (at least eight different ligands, including the neuregulins, are produced in high quantities in the nervous system and the mesenchyme). It is worth noting that EGFR:EGFR homodimers and EGFR:ErbB2 heterodimers are not known to bind the neuregulins and are primarily activated by epidermal growth factor (EGF), transforming growth factor $\alpha(\mathrm{TGF} \alpha)$ and amphiregulin (AR). Because adult taste cells expressing high levels of ErbB3 appear to be much less numerous than those that express EGFR and $\mathrm{ErbB} 2$, the EGF, TGF $\alpha$, and AR ligands may affect greater numbers of adult taste cells than do the neuregulins.

$\left[{ }^{3} \mathrm{H}\right]$ thymidine labeling experiments by Delay et al. (1986) indicate that basal cells are the first cells to appear in taste buds and that differentiated taste receptor cells are derived from this cell type. In addition to its expression in differentiated taste cells, high levels of ErbB2 expression can also be detected in taste bud basal cells, and some ErbB2 ${ }^{+}$taste cells have a morphology intermediate between that of a basal cell and that of a mature taste receptor cell. It appears that ErbB2 is the only Erb receptor expressed by the taste bud basal cells, and because ErbB2 is incapable of signaling on its own (at least in response to the known Erb ligands), its solitary presence in these cells is problematic. There are several possible explanations: (1) the expression of ErbB2 in the basal cells is nonfunctional, and the receptor is only activated when the cells are mature enough to express other Erb receptors; (2) the ErbB2 receptor functions by forming heterodimers with another Erb receptor that is expressed in these cells at low levels; and (3) ErbB2 is responding as a homodimer to an as yet unidentified ligand.

\section{Erb receptors during development}

EGFR, ErbB2, and ErbB3 are expressed during prenatal and postnatal development in and around circumvallate and foliate gustatory papillae and in cells within developing taste buds in these papillae. The reduced numbers and aberrant morphology of fungiform taste buds in EGFR knockout mice suggest that EGFR plays a prominent role in the development of these papillae and their taste buds; however, the circumvallate and foliate gustatory papillae in these mice appear to be normal (Miettinen et al., 1995; Threadgill et al., 1995; Oakley and Sun, 1999). Therefore, the role of EGFR in the formation of circumvallate and foliate papillae is uncertain. Perhaps the loss of EGFR in the knockout mice may produce a subtle defect in these papillae that is not easily detected, or perhaps its loss is compensated for by other factors. Alternatively, EGFR may not play a significant role in the development of circumvallate and foliate papillae, and if Erb receptors regulate the development of these papillae, the functional Erb dimer may be ErbB2:ErbB3. Experiments have shown that neuregulin mRNA is found in the VII and IX cranial sensory ganglia (whose branches innervate taste buds in circumvallate and foliate papillae), and NRGs and other Erb ligands are commonly produced by mesenchymal cells (Meyer and Birchmeier, 1994). Thus the Erb receptors expressed in taste buds are potentially capable of being activated by Erb ligands in the surrounding mesenchyme or on innervating neurons.

\section{c-Kit is expressed in taste receptor cells and in neuronal fibers around developing taste papillae} c-Kit expression in adult taste buds

In adult gustatory papillae, c-kit is expressed in taste buds and cannot be detected in the surrounding epithelium or in the lingual mesenchyme. c-Kit is primarily expressed by the differentiated 
spindle-shaped cells of the taste bud rather than by the basal cells. What might be the function of c-kit in the differentiated taste cell? Takeda et al. (1996) showed that apoptotic cells are present in vallate taste buds and that the number of these cells dramatically increases on gustatory nerve sectioning. The c-kit ligand stem cell factor (SCF) (Blume-Jensen et al., 1998) as well as the Erb NRG ligands (Grinspan et al., 1996; Trachtenberg and Thompson, 1996) have been implicated in the prevention of apoptosis in other cell types. Thus, one function of c-kit (and perhaps of the Erb receptors) on differentiated taste cells may be to maintain the differentiated state and prevent apoptosis.

\section{c-Kit receptor in developing taste buds}

During the development of the circumvallate and foliate papillae, the c-kit receptor is expressed at high levels in three main locations: (1) in neuronal fibers in the papillary core and around the papillae trenches, (2) in isolated cells in the taste bud-forming region of the papillae epithelium, and (3) in a punctate pattern at the tips of the circumvallate papillae and the bottom of the foliate papillae trenches.

c-Kit and SCF have been detected in neural crest-derived cranial and dorsal root ganglia, in central and peripheral neurons, and in various craniofacial structures (Matsui et al., 1990; Keshet et al., 1991; Zhang and Federoff, 1997). SCF can act as a neurotrophic factor for some neurons (Hirata et al., 1993; Carnahan et al., 1994), and it has been suggested that c-kit is involved in the development of neuronal connections. An examination of the expression of SCF in and around taste papillae during development would be a first step in determining whether SCF could act in conjunction with $\mathrm{BDNF}$ in facilitating the interaction between gustatory neurons and taste buds.

By P2, multiple brightly stained c-kit ${ }^{+}$cells can be seen in the taste bud-forming regions of the circumvallate and foliate papillae, the same time at which ErbB2 ${ }^{+}$cells appear. On the basis of their location, they are likely to be recently differentiated taste cells. The expression of c-kit by these immature taste cells suggests that c-kit may be involved in promoting their maturation. This type of role for c-kit is not unprecedented, because c-kit is required for the postnatal development of the pacemaker cells of the gut, the interstitial cells of Cajal (Kluppel et al., 1998).

Cells at the tips of circumvallate papillae and at the bottom of foliate papillae trenches exhibit a punctate $\mathrm{c}-\mathrm{kit}^{+}{ }^{+}$staining that begins at P3, is at its peak by P6, and is gone by P10. c-Kit could therefore be involved in deepening the foliate papillae, or it could be important for the development of von Ebner's glands, which drain into the gustatory papillae trenches. Interestingly, Oakley et al. (1991) showed that new taste buds are added primarily at the rostral and caudal ends of the circumvallate papillae early during postnatal development. It has been reported that there is a sensitive period for postnatal taste bud induction between P0 and P10 (Hosley et al., 1987; Oakley, 1993) during which taste stem cells may become determined. The expression of the c-kit receptor during a sensitive period for taste bud induction in regions of the papillae where new taste buds are being added could therefore implicate it in the postnatal development or determination of taste stem cells, or both.

The distinctive expression patterns of the Erb and c-kit receptors described in these experiments suggests that these protein tyrosine kinases could play a role in the maintenance and regeneration of adult taste buds, as well as in the prenatal and postnatal development of taste buds and gustatory papillae. A further examination of the expression of these receptors and their ligands in and around taste papillae could begin to answer some of the many questions that remain regarding gustatory development and regeneration.

\section{REFERENCES}

Barlow LA, Northcutt RG (1997) Taste buds develop autonomously from endoderm without induction by cephalic neural crest or paraxial mesoderm. Development 124:949-957.

Barlow LA, Chien C-B, Northcutt RG (1996) Embryonic taste buds develop in the absence of innervation. Development 122:1103-1111.
Barry MA, Savoy LD (1993) Persistence and calcium-dependent ATPase staining of denervated fungiform taste buds in the hamster. Arch Oral Biol 38:5-15.

Beidler LM, Smallman RL (1965) Renewal of cells within taste buds. J Cell Biol 27:263-272.

Besmer P, Manova K, Duttlinger R, Huang EJ, Packer A, Gyssler C, Bachvarova RF (1993) The kit-ligand (steel factor) and its receptor c-kit/W: pleiotropic roles in gametogenesis and melanogenesis. Development [Suppl] 125-137.

Birchmeier C, Sonnenberg E, Weider KM, Walter B (1993) Tyrosine kinase receptors in the control of epithelial growth and morphogenesis during development. Bioessays 15:185-190.

Blume-Jensen P, Janknecht R, Hunter T (1998) The Kit receptor promotes cell survival via activation of PI 3-kinase and subsequent Aktmediated phosphorylation of Bad on Ser136. Curr Biol 8:779-782.

Boughter JD, Pumplin DW, Yu C, Christy RC, Smith DV (1997) Differential expression of $\alpha$-gustducin in taste bud populations of the rat and hamster. J Neurosci 17:2852-2858.

Bradley RM, Mistretta CM (1988) Development of taste. In: Handbook of human growth and developmental biology, Vol 1, Part B. Sensory, motor, and integrative development. (Meisami E, Timiras PS, eds), pp 63-78. Boca Raton, FL: CRC.

Burden S, Yarden Y (1997) Neuregulins and their receptors: a versatile signaling module in organogenesis and oncogenesis. Neuron 18:847-855.

Carnahan JF, Patel DR, Miller JA (1994) Stem cell factor is a neurotrophic factor for neural crest-derived chick sensory neurons. J Neurosci 14:1433-1440.

Delay RJ, Kinnamon JC, Roper CD (1986) Ultrastructure of mouse vallate taste buds: II. Cell types and cell lineage. J Comp Neurol 253:242-252.

Farbman AI, Mbiene JP (1991) Early development and innervation of taste bud-bearing papillae on the rat tongue. J Comp Neurol 304:172-186.

Fritzsch B, Sarai PA, Barbacid M, Silos-Santiago I (1997) Mice with a targeted disruption of the neurotrophin receptor trkB lose their gustatory ganglion cells but do develop taste buds. Int J Dev Neurosci 15:563-576.

Gassman M, Lemke G (1997) Neuregulins and neuregulin receptors in neural development. Curr Opin Neurobiol 7:87-92.

Grinspan JB, Marchionni MA, Reeves M, Coulaloglou M, Scherer SS (1996) Axonal interactions regulate Schwann cell apoptosis in developing peripheral nerve: neuregulin receptors and the role of neuregulins. J Neurosci 16:6107-6118.

Guth L (1958) Taste buds on the cat's circumvallate papilla after reinnervation by glossopharyngeal, vagus, and hypoglossal nerves. Anat Rec 128:715-731.

Hall JM, Hooper JE, Finger TE (1999) Expression of sonic hedgehog, patched, and Gli1 in developing taste papillae of the mouse. J Comp Neurol 406:143-155.

Hirata T, Morii E, Morimoto M, Kasugai T, Tsujimura T, Hirota S, Kanakura Y, Nomura S, Kitamura Y (1993) Stem cell factor induces outgrowth of c-kit-positive neurites and supports the survival of c-kitpositive neurons in dorsal root ganglia of mouse embryos. Development 119:49-56.

Hosley MA, Oakley B (1987) Development of the vallate papilla and taste buds in rats. Anat Rec 218:216-222.

Hosley MA, Hughes SE, Morton LL, Oakley B (1987) A sensitive period for the neural induction of taste buds. J Neurosci 7:2075-2080.

Keshet E, Lyman SD, Williams DE, Anderson DM, Jenkins NA, Copeland NG, Parada LF (1991) Embryonic RNA expression patterns of the c-kit receptor and its cognate ligand suggest multiple functional roles in mouse development. EMBO J 10:2425-2435.

Kinnman E, Aldskogius H (1991) The role of substance P and calcitonin gene-related peptide containing nerve fibers in maintaining fungiform taste buds in the rat after chronic chorda tympani nerve injury. Exp Neurol 113:85-91.

Kluppel M, Huizinga JD, Malysz J, Bernstein A (1998) Developmental origin and kit-dependent development of the interstitial cells of Cajal in the mammalian small intestine. Dev Dyn 211:60-71.

Lai C, Lemke G (1991) An extended family of protein-tyrosine kinase genes differentially expressed in the vertebrate nervous system. Neuron 6:691-704.

Lee MK, Tuttle JB, Rebhun LI, Cleveland DW, Frankfurter A (1990) The expression and posttranslational modification of a neuron-specific beta-tubulin isotype during chick embryogenesis. Cell Motil Cytoskel 17:118-132.

Matsui Y, Zsebo KM, Hogan BLM (1990) Embryonic expression of a haematopoietic growth factor encoded by the Sl locus and the ligand for c-kit. Nature 347:668-669.

Mbiene JP, Mistretta CM (1997) Initial innervation of embryonic rat tongue and developing taste papillae: nerves follow distinctive and spatially restricted pathways. Acta Anat 160:139-158.

Mbiene J-P, MacCallum DK, Mistretta CM (1997) Organ cultures of embryonic rat tongue support tongue and gustatory papilla morphogenesis in vitro without intact sensory ganglia. J Comp Neurol 377:324-340.

McLaughlin SK, McKinnon PJ, Margolskee RF (1992) Gustducin is a taste-cell-specific $G$ protein closely related to the transducins. Nature 357:563-568.

Meyer D, Birchmeier C (1994) Distinct isoforms of neuregulin are ex- 
pressed in mesenchymal and neuronal cells during mouse development. Proc Natl Acad Sci USA 91:1064-1068.

Miettinen PJ, Berger JE, Meneses J, Phung Y, Pedersen RA, Werb Z, Derynck R (1995) Epithelial immaturity and multiorgan failure in mice lacking epidermal growth factor receptor. Nature 376:337-341.

Mistretta CM (1972) Topographical and histological study of the developing rat tongue, palate and taste buds. In: Third symposium on ora sensation and perception: the mouth of the infant (Bosma JF, ed), pp 163-187. Springfield, IL: Thomas.

Mistretta CM, Goosens KA, Farinas I, Reichardt LF (1999) Alterations in size, number, and morphology of gustatory papillae and taste buds in BDNF null mutant mice demonstrate neural dependence of developing taste organs. J Comp Neurol 409:13-24.

Morrison-Graham K, Takahashi Y (1993) Steel factor and c-kit receptor: from mutants to a growth factor system. BioEssays 15:77-82.

Nosrat CA, Blomlof J, ElShamy WM, Ernfors P, Olson L (1997) Lingual deficits in BDNF and NT3 mutant mice leading to gustatory and somatosensory disturbances, respectively. Development 124:1333-1342.

Oakley B (1974) On the specification of taste neurons in the rat tongue. Brain Res 75:85-96.

Oakley B (1993) The gustatory competence of the lingual epithelium requires neonatal innervation. Brain Res Dev Brain Res 72:259-264.

Oakley B, Sun H (1999) Epidermal growth factor receptors control the differentiation of fungiform taste receptor cells. Soc Neurosci Abstr 25:1051.

Oakley B, LaBelle DE, Ripley RA, Wilson K, Wu L-H (1991) The rate and locus of development of rat vallate taste buds. Dev Brain Res 58:215-221.

Oakley B, Brandemihl A, Cooper D, Lau D, Lawton A, Zhang C (1998) The morphogenesis of mouse gustatory vallate epithelium and taste buds requires BDNF-dependent taste neurons. Dev Brain Res 105:85-96.

Olmsted JMD (1921) Effects of cutting the lingual nerve of the dog. J Comp Neurol 33:149-154.
Olmsted JMD (1922) Taste fibers and the chorda tympani nerve. J Comp Neurol 34:337-341.

Roper SD (1989) The cell biology of vertebrate taste receptors. Annu Rev Neurosci 12:329-353.

Sloan HE, Hughes E, Oakley B (1983) Chronic impairment of axonal transport eliminates taste responses and taste buds. J Neurosci 3:117-123.

Takeda M, Suzuki Y, Obara N, Nagai Y(1996) Apoptosis in mouse taste buds after denervation. Cell Tissue Res 286:55-62.

Threadgill DW, Dlugosz AA, Hansen LA, Tennenbaum T, Lichti U, Yee D, LaMantia C, Mourton T, Herrup K, Harris R, Barnard JA, Yuspa SH, Coffey RJ, Magnuson T (1995) Targeted disruption of mouse EGF receptor: effect of genetic background on mutant phenotype. Science 269:230-234.

Trachtenberg JT, Thompson WJ (1996) Schwann cell apoptosis at developing neuromuscular junctions is regulated by glial growth factor. Nature 379:174-177.

Vintschgau MV, Honigschmied J (1876) Nervus Glossopharyngeus und Schmeckbecher. Arch ges Physiol 14:443-448.

Wilkie TM, Simon MI (1991) Cloning multigene families with degenerate PCR primers. Methods 2:32-41.

Wong GT, Gannon KS, Margolskee RF (1996) Transduction of bitter and sweet taste by gustducin. Nature 381:796-800.

Zalewski AA (1969) Combined effects of testosterone and motor, sensory, or gustatory nerve reinnervation on the regeneration of taste buds. Exp Neurol 24:285-297.

Zalewski AA (1970) Regeneration of taste buds in the lingual epithelium after excision of the vallate papillae. Exp Neurol 26:621-629.

Zhang S-C, Federoff S (1997) Cellular localization of stem cell factor and c-kit receptor in mouse nervous system. J Neurosci Res 47:1-15.

Zhang C, Brandemihl A, Lau D, Lawton A, Oakley B (1997) BDNF is required for the normal development of taste neurons in vivo. NeuroReport 8:1013-1017. 